\title{
Transformational leadership style: a boost or hindrance to team performance in IT sector
}

\author{
Deepak Jaroliya \\ Prestige Institute of Management and Research, Indore, India, and \\ Rajni Gyanchandani \\ Research Scholar, Prestige Institute of Management and Research, Indore, India
}

\begin{abstract}
Purpose - A leader plays an important role in the growth of an organization. The leader is a person who influences the standards, structure, culture and behaviour of the individuals employed in the organization. A leader also has effects on the result and productivity of teams. The purpose of this paper is to analyze the effect of transformational leadership style on team performance. This paper will also analyze the existence of a relationship between transformational leadership style and team performance.

Design/methodology/approach - For this study, the researcher collected the data from 354 individuals employed in IT organizations in Pune. The team members answered questions asked about the transformational leadership style, and the team leaders answered questions related to team performance. The data has been analyzed using the latest available version of Statistical Product and Service Solutions.

Findings - The results of this examination suggest that there is strong and positive relationship between the transformational leadership style and team performance. Further, it was also found that transformational leader helps in a great way in improving team performance which in turn increases the organization's productivity.

Research limitations/implications - Few limitations of this research work are that the data collected for this research work is non-cognitive in nature and simultaneously respondents may incline to evaluate the positive facets of opinion poll more propitiously than negative facets. Secondly, the data have been collected only from companies located in Pune.

Practical implications - This research study provides empirical data that will be helpful for human resources department of an organization, as it can help them in the development of policies and practices. It will also provide help leaders to support employees who are seeking effective ways to support struggling employees in context to their team performance.

Originality/value - The present study can be differentiated from past studies, as it thinks over an ensemble of transformational leadership style as an essential antecedent of team performance and also enhances the knowledge of the researchers and practitioners about the leadership style that upshot to the team performance. This will also help the managers, researchers, organizational development specialist and employees who are seeking effective ways to support struggling employees in context to their team performance.
\end{abstract}

Keywords Team performance, Leadership, IT sector, Transformational, Leadership style

Paper type Research paper

(C) Deepak Jaroliya and Rajni Gyanchandani. Published in Vilakshan - XIMB Journal of Management. Published by Emerald Publishing Limited. This article is published under the Creative Commons Attribution (CC BY 4.0) licence. Anyone may reproduce, distribute, translate and create derivative works of this article (for both commercial and non-commercial purposes), subject to full attribution to the original publication and authors. The full terms of this licence maybe seen at http:// creativecommons.org/licences/by/4.0/legalcode 
XJM

19,1

\section{Introduction}

Leader is a person who fascinates the people who are required to accomplish organizational goals. Countries, corporates and people unequivocally or certainly strive to become leaders in their space. Different organizations have different perspectives on leadership; it varies as per the overall structure of understanding expected by individual leaders with respect to their individual expectations (Khan, 2017). As rightly pointed by Stogdill (1974), there are approximately equivalent number of definitions of leadership as there are individuals who have made an effort to describe the idea. The result of this is that in the previous 50 years, there have been as many as 60 distinctive classification frameworks created to describe the components of leadership (Fleishman, 1991). Over the last few decades one such theory of leadership, which pulled in much consideration of scientists and academicians in ongoing past, is transformational leadership (Castelli, 2016).

Recent and past meta-examinations bolster the theorizing that transformational leaders motivates their team members to rise above their own objectives and focus on overall objectives of the organization, advance their responsibilities, freedom, exertion and execution (DeGroot, 2000); (Judge, 2004). The building block of any organization is team performance that is an imperious for the organization. It is essential for the organizations to understand the aspects which make the teams to work towards accomplishment of goal. Successively, the progress of any organization is dependent on the team's effort and not on efforts of a few individual's. The multifaceted worldwide view is performance intended to accomplish the anticipated outcomes and has a substantial association in achieving the significant objectives of any organization (Mwita, 2000) and for accomplishment of these objectives, the most important variable to be considered is leadership style of team leaders. Additionally, it has been commonly recognized that the performance of any group is to a great extent reliant on authority style of its leader (Jones and Rudd, 2008). The leader has an impending influence on team performance. The choices that the pioneer makes can lead to progress or setbacks of the organization. The need of effective leader increases with the growth of the organization. As per Burns (1978), transformational leadership speaks to an authority style that is epitomized by attraction and mutual acumen among pioneers and adherents. The transformational leader's vitality can be observed from their ability to invigorate and persuade everyone to make important work. As per Bass (1999), transformational leadership takes place at the point when leaders expand as well as intrigues their representatives, as soon as they create mindfulness and acceptance of the reasons and objectives of the team, and at the time they stimulate their team members to fore glimpse their own specific interest for the interest of the team. So it can be assumed that there is a sturdy relationship between leadership style and team performance in any organization.

\section{Literature review}

Leadership is an ability to motivate, boost confidence and to support teams that works towards the achievement of organizational goals (Kim, 1992). Leadership is a process of exercising pressure intentionally on people, to direct the organization and expedite the actions and associations in either a team or an organization (Yukl, 2013). According to Khan (2017), leader plays an important role in the organization by ensuring that projected leadership style should influence its team members. Fiedler (1996) is one of the most esteemed leadership researchers, who talks about the association between leadership and team performance and found that progress or setback of a team, organization or whole society is dependent on leader's effectiveness to lead them. It is only leadership style that can make or break an organization. Leaders hold the key position in an organization and leader's 
efficiency to lead a team is a very important factor, which defines the progress or setbacks of a team. One of the most significant aspects in increasing or impeding the interest of the people or teams in any organization is leadership (Obiwuru et al., 2011; Gillet, 2014). Success of a team means attainment of goals and objectives effectively and efficiently, and it is totally dependent upon the leadership style of team leaders (Mokgolo, 2012).

Different authors have propounded different theories and leadership styles periodically. The most governing topology of leadership styles is enunciated by Bass $(1980,1997)$ and his companions (Bass, 1987). It was in fact Burns (1978) who worked on the leadership as well as promulgated the model by way of transactional and transformational leadership styles, however, far ahead Bass and Avolio $(1980,1997)$ advanced the model. Burns (1978) defined transformational leader as a leader who is competent to encourage admirers up from their insignificant worries and make them work for a mutual objective and to attain things not at all believed to be possible. A latest study conducted by Tepper (2018) shown that team members behave well when managed by transformational leaders, particularly when they encounter most formidable distress at work. Transformational leaders, specifically, emphasizes on "vision" and have a "shared" direction with their team members (Wang, 2014; Khan, 2017; Thomas, 2017) instead of influencing them in conventional manners. Transformational leadership is widely trusted style of leadership (Collins, 2014). According to Yukl (2013), transformational leadership is the method of inducing the important shifts in the perspectives and presumptions of members of team and makes them committed for the team goals or purposes. Transformational leader's incorporates exemplar, create special bonds with team members, motivates them, encourages for brainstorming and also for active observation for accomplishing highest echelons (Singh and Krishnan, 2007; Rotberg, 2014; Somboonpakom, 2014). Transformational leader has considerable effect on teams innovativeness and originality at work, a few of them are vision, separate independence, appreciation, inspiration and taking challenges. Transformational leader is a proactive person; he encourages unique and ingenious ideas, inspires and emancipates the teams to achieve the pre-determined objectives, by integrating new insights and code of ethics. Transformational leaders make sure optimistic ethological changes which can be seen in terms of enhanced team's efficiency and innovativeness among the individuals in any organization (Gumusluoglu and Isev, 2007; Bacha, 2014). The leader makes the team member mindful and ready to achieve beyond their expectations and perceived capabilities (Palestini, 2009; Avolio, 2010). All the theoretical and empirical research that has been conducted on transformational leadership suggested that it boost team member's performance and helping behavior (Chun, 2016). It has been summarized by Crane (2018), Zach (2018) that transformational leaders can resolve employee's mental complexity through proper guidance and by providing them required feedback. A leader can be considered as truly transformational if he/she creates the cognizance of righteousness, moral, significant and attractive, at the time they assist the followers in lifting their desires for accomplishment and self-fulfillment, at the time they nurture team members good spirit as well as encourages them to work far away from their self-interests for the best of their team, company or the community. As per Susan (2014), there are five main components of transformational leadership:

(1) idealized influence;

(2) attributive charisma;

(3) individual consideration;

(4) inspirational motivation; and

(5) intellectual stimulation. 
Many researchers suggested that idealized influence refers that leader compelling activities that emphasis on morals, opinions and vision (Carasco-Saul, 2015; Tajasom, 2015; Van Knippenberg, 2013). The leader stimulates esteem, appreciation and devotion among team members and lines them to assent as well as accomplish team's goal collectively. Leader's attributive charisma states that leader's societal attractiveness and specifies opinion for the leader as being assertive and influential (Bass, 1990). By individual consideration means a pioneer focuses on people bond, i.e. he/she focuses on maintaining the association with each and every team members. The leader recognizes and watches out subordinates various needs, sentiments, expertise and ambitions (Winkler, 2010; Dionne, 2010; John, 2014). By inspirational motivation means the leader enunciates the dream among the team members and also persuades them to accept this dream, displaying various means to accomplish team objectives and develop confidence in them that they can accomplish it (Yukl, 2013; Ndunge, 2014). Through intellectual stimulation, the leader magnifies and expands the intellectual ability of team members, prepares them intellectually for resolving the professional issues with novel approaches and improvements (Judge and Piccolo, 2004; Hancott, 2005; Northouse, 2015).

Transformational leadership is exceptionally compelling as far as follower's development and performance is concerned. Regardless of the fact that investigate on transformational leadership has constantly observed that there is a fundamental procedure by which transformational leaders shows their effect on their subordinate's growth and in due course raise their spirits team to perform its best. (Dvir, 2002); (Walumbwa, 2004); (Wang, 2012), astoundingly comparatively slight investigation has been done on this topic particularly in IT sector in team settings.

According to Moura (2018), Haque (2017) modifications in the commercial center and in the personnel prompted a necessity to embrace a transformational leadership style. These pioneers cultivate adherents to go beyond their own expedience, lifting their development just as indicating worry for accomplishment, self-completion and prosperity of subordinates. By this way the leaders influence the adherent's qualities, feelings, perspectives and rouse them to carry out their task past their desires (Yukl, 2013). By steering team members towards more noteworthy degrees of accomplishment, transformational leadership has become critical to encourage performance of team. A study conducted by Tepper (2018) found that transformational leader makes team members respond better particularly at the time they face more challenges in their work. The researches on transformational leadership theory and performance endorses the relationship within these two develops (Avolio, 2010). Different investigations show that transformational leadership is recognized to bring constructive group results in different occupational settings, both governmental and non-governmental (Bass, 2009; Trottier, 2008).

Transformational leaders have the art of convincing, inspiring and stimulating team members to think creatively (Fernet, 2015). Transformational leaders have the ability to rouse followers to function more earnestly and go beyond as is estimated for the benefit of the team (Polychroniou, 2009). Therefore, transformational leaders make followers more dedicated towards the task of the team and thus bound them to cooperate after a while, execute better approaches for functioning and have a superior functional understanding. Altogether, team performance would be improved (Strauss, 2009). They additionally reframe administrative environment to permit team members to be to be completely engaged with various aspects of their task (Thomas, 2017). All things considered, workers have more opportunities to associate themselves to new circumstances in the work environment, which can make team members flexible (Wang, 2017). In the current investigation, we will analyze the relationship between transformational leadership and team performance, using organizational teams of IT sector. 

dimensional and common phenomenon for any organization. Although the concept of team performance has been studied a lot by different academicians and researchers, there is unanimous agreement on its definition and measurement criteria. In many research performance behaviors and outcomes has been discriminated, various examinations have utilized unified or a multiple measurement of team results. Lester and colleagues (2002), indicated performance as meeting fundamental needs, accomplishing goals, as well as identifying important endurance aspects. Similarly, Hiller (2006) used a scale of efficiency consist of planning, cognitive ability, support and consideration, coaching and improvement, as well as overall effectiveness. Likewise, Van der Vegt (2005) had focused on supervisors rating on efficiency, quality, overall achievement, productivity and mission fulfillment of team. Barrick (1998) incorporated wisdom; excellence; magnitude; initiative; social skills; planning and overall commitment in their measure of performance.

According to Pawirosumarto (2017), Edmonson (2017) performance of a team is typically centered on the team member's knowledge, expertise, knowhow and behavior; required to accomplish a task. Almost all the organizations highlight on individuals team performance, as it is an imperative component in attaining sustainable competitive edge.

It has been found in the research conducted by Marieke van der Hoek (2016), Moura (2018) that mutual trust is the most important factor that affects the team performance. It means that if mutual trust is present among members of team then team environment will be good which will make employees feel relaxed and comfortable to work with each other and will feel accountable and as result enhances team performance. Cohen (1997) categorized team outcomes into three groups: performance; attitudes and behaviours. Though, the conditions to measure the performance of team have transformed in the last few years and incorporated wide variety of methods and amalgamations. Along these lines, what establishes "viability" had become increasingly multifaceted past several years (Mathieu, 2008).

Regardless of the accessibility of numerous points of view and representations of team performance (Lourenço, 2004), team performance is a concept that is arduous and difficult to describe, as it has no relation to a goal reality. Or maybe, it had been recommended that adequacy ought to be broke down as well as estimated by the qualities, benefits, as well as inclinations of the on-screen characters also of frameworks to which it alludes to Dimas (2016).

Hackman (2012), Bhatnagar (2012) offered a paradigm for evaluating team performance that got extensive approval. As indicated by this paradigm, team performance is characterized as well as can be assessed using three unique conditions:

(1) the level to which product or service of a team fulfills, or transcends, the criteria of both quantity and quality of the individuals who would be given or evaluate and/ or utilizes it;

(2) how much social processes inside the team keep up, or improve, the ability of the gathering to cooperate as well as turn into a progressively capable and most successful unit after some time; and

(3) how much the fulfills individuals' needs and expands individuals' fulfillment, prosperity and advancement.

In accordance with this grasping point of view, in the current paper we considered following criteria to evaluate team performance: service and product satisfaction to clients, top quality 
services, successfully target accomplishment, high performance team, quickly fulfillment of work demand, meet required work deadlines, highly productive, met the set standard and renowned by other service teams for its high performance.

This research work is an endeavor to riposte as to how much effect does transformational leadership have on the team performance of any organization as well as to what degree does the transformational leadership style applied in any association assist team members in executing their tasks or aids in performing the tasks allotted to them. The main goal of the current research examination is to analyze the effect of transformational leadership style on team performance. The ramification of present investigation is to assist leaders of organization belongs to IT sector to recognize the style of leadership favored by their team members to upgrade their team performance and as almost all IT organizations have moved away from traditional hierarchical model towards dynamic team based organizational structure so it has been decided to by researchers considered IT Sector for the present study.

In accordance with this grasping point of view, in the present study, authors have considered following criteria to evaluate team performance: service and product satisfaction to clients; top quality services; successfully target accomplishment; high performance team; quickly fulfillment of work demand; meet required work deadlines; highly productive; met the set standard and renowned by other service teams for its high performance.

This has motivated researchers to come up with idea to conduct a research to understand the effect of leadership styles on team performance. It has been decided to conduct the present study specifically in the IT sector because of its dynamic and team based working culture.

\section{Research gap}

The substantial number of research studies has been conducted on leadership styles (Basham, 2012; Bolden, Gosling, O’Brien, Peters, Ryan and Haslam, 2012; Herbst and Conradie, 2011; López- Domínguez, Enache, Sallan and Simo, 2014; Sani and Maharani, 2012; Vinger, 2009) in the higher education and other sectors in numerous countries. Precisely, sufficient proofs of empirical studies are available on leadership styles and team performance in schools, universities, military, insurance sector, banking sector and so on. Although, these studies are different broadly with respect to circumstance, objectives and methodology.

There is testimony to this, as limited studies have been conducted in the subject of transformational leadership in India in few sectors; strangely, studies on the effect of transformational leadership styles on various outcomes such as knowledge creation in Indian software industry (Athukorala, Perera and Meedeniya, 2016), employee' performance in banking industry (Chamika and Gunasekara, 2016), union and organizational commitment in public sector organizations in India (Dhammika, Ahmad and Sam, 2013), etc.

But, still there is requirement for studies in the area of leadership styles in IT sector in India, where the cultural traits like beliefs, attitudes and behaviours vary remarkably. Besides this, earlier researches has distinctly applied varied types of leadership styles like autocratic and democratic leadership, servant leadership and authentic leadership and task and people oriented leadership styles to study the elements of interest. Hence, gap exists in the present literature exploring the effects of transformational leadership style on team performance in Indian context.

Furthermore, methodological problems are there with maximum prevailing studies. The most of field studies have been cross-sectional in design, and the common-method bias usually has been an issue when performance has been measured (Barling et al., 2002; Jermier 
and Kerr, 1997). The quality of performance measurement is important in finding the outcomes about the degree to which leadership matters and not all researches have been well devised (Dionne et al., 2002). Inside the Indian corporate area, it is extremely uncommon to run over investigations which have been directed on the effect of transformational leadership style on team performance in IT Sector. Accordingly the goal of the researcher was to discover how far the transformational leadership style progress toward becoming parameters affecting team performance in IT Sector which is a booming sector in India.

\subsection{Research objectives}

- To analyze the existence of a relationship between transformational leadership style and team performance in IT sector.

- To analyze the effect of transformational leadership style on team performance in IT sector.

Following conceptual model as shown below in Figure 1 being proposed by authors that highlights the relationship between transformation leadership style and team performance along with existing variables/factors. This model will be analyzed carefully to achieve the objective of the present study.

\section{Research method}

The objective of this research can be achieved by examining the proposed model and for this; the quantitative survey design was used by researchers to accomplish research objectives.

\subsection{Research instrument}

Standard Scale - The MLQ (Multifactor Leadership Rater Questionnaire 36 items) developed by Bass (2000), Mind Garden, was used to measure the transformational leadership style. From the MLQ "long form" 20 items of transformational leadership have been taken. The scale consists of 20 items, with four items for each factor. Transformational leadership style consisted of 20 items and the facets of which are idealized influence (attributed - 4 items), idealized influence (behavior -4 items), inspirational motivation (4 items), intellectual

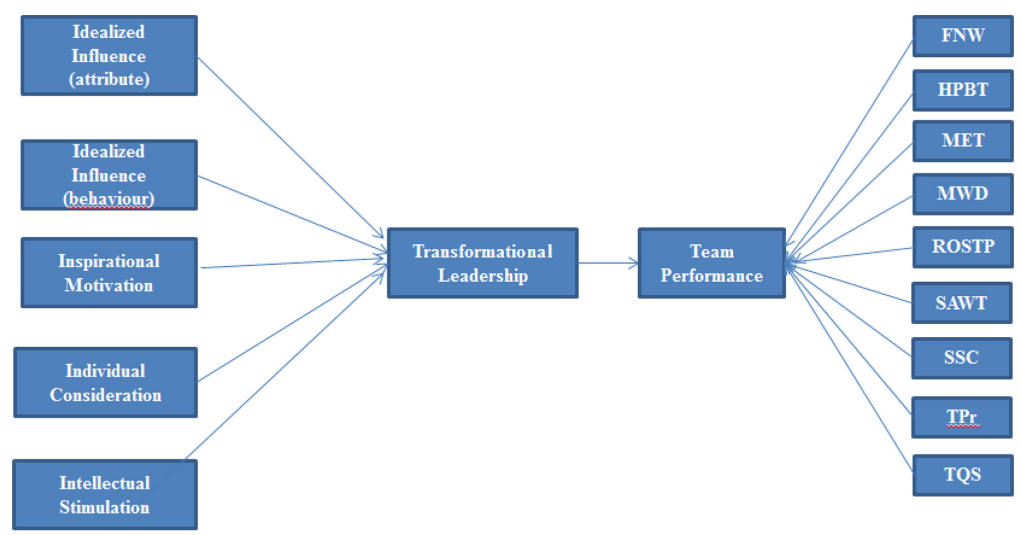

Source: Developed by Authors

Figure 1. Proposed conceptual model 
stimulation (4 items) and individualized consideration (4 items). The items of transformational leadership style were rated on a five-point Likert scale $(1=$ Strongly Disagree, $2=$ Disagree, $3=$ Neutral, $4=$ Agree and $5=$ Strongly Agree) .

Self-designed Questionnaire - A self-designed nine-item leadership outcome questionnaire was used to measure the team performance. The questionnaire consists of nine variable to measure team performance, i.e. service and product satisfaction to clients, top quality services, successfully target accomplishment, high performance team, quickly fulfillment of work demand, meet required work deadlines, highly productive, met the set standard and renowned by other service teams for its high performance. The items of team performance were rated on a five-point Likert scale $(1=$ Strongly Disagree, 2 = Disagree, $3=$ Neutral, $4=$ Agree and $5=$ Strongly Agree).

\subsection{Research participants and procedure}

The respondents for this survey were employees working in IT organizations in Pune. It has been decided to conduct the present study specifically in the IT sector because of its dynamic and team based working culture. Two different tools were used to collect data from team members (Standard Leadership Scale-Avolio and Bass, 2004) and team leaders (Team Performance Questionnaire-Developed by Authors). These components of team performance were evaluated by team leaders on the basis of the work of their team members. According to Rousseau (2010) team leaders are the best knowledgeable people about the outcomes of their individual teams and can accurately evaluate their performance. Transformational leadership style questionnaire was answered by team members; as they are the one who work closely with the team leader and observe their leader so they will be able to accurately answer the questions related to their leader's leadership style.

Anonymous questionnaires were distributed to team leaders and their subordinates by researchers to total 500 employees and requested to the participants to complete themselves. Both paper and online surveys were used to collect data. Non-probability judgment sampling technique was used to choose the sample. The respondents have chosen on the basis of judgment sampling. The purpose behind selecting a non-probability sampling technique was that the sample frame could not be established as the population was unknown. Judgmental sampling was taken into consideration as an appropriate sampling technique as the respondents were to be chosen considering few conditions. The following criterion has been used to select the sample:

- The group must be officially perceived in the organization as a team.

- At least five members should be there in a team (excluding the leader).

- The leader (supervisor) must be officially acknowledged, too.

- The respondent should have at least 1 year of experience in IT Sector.

- The respondent should be a member of a team either subordinate or a team leader.

The participants completed 400 questionnaires out of which 354 found to be valid and thus the response rate was $88.5 \%$ that is satisfactory in social science. Out of the total respondents $69 \%$ were male and $31 \%$ were female employed in the IT sector in Pune.

\section{Statistical analysis and results}

The researcher used correlation analysis to measure the relationship between dependent (Team performance) and independent variable (Transformational Leadership Style). To identify the effect of transformational leadership on team performance linear regression 
analysis was performed. The researchers used descriptive and inferential statistics to analyze the data.

With the aim of this study, correlation analysis was used to determine the relationship between dependent variable (Team Performance) and independent variable (Transformational Leadership Style). The findings of the study discovered a high correlation between transformational leadership and team performance. Transformational leadership is significantly related with team performance $(r=0.778, p<0.01)$. Further, the researcher measured the correlation between transformational leadership subscales, i.e. idealized influence (A), idealized influence (B), inspirational motivation, intellectual stimulation and individualized consideration with team performance. The result of these relationships is presented in Table 1.

Table 1 indicates that there is a positive and significant relationship exists between transformational leadership style and team performance. It indicates that leadership conducts that encompass stimulating a shared dream, encouraging innovation, growth, strengthen confidence, acknowledging team endeavors encourages the individuals to carry out the tasks in a team and the presence all these factors inspire the team outperform for accomplishment of organizational goal.

Idealized influence (attributed) positively correlated with team performance, $r=1.00$, $p<0.01$. There was also a positive correlation between Idealized Influence (behavior) $r=0.649, p<0.01$ Inspirational motivation and team performance also positively related, $r=0.520 p<0.01$. Intellectual stimulation positively correlated with team performance, $r=$ $0.539, p<0.01$. There was also a strong and positive correlation between Individualized consideration, $r=0.598, p<0.01$. It can be summarized that the results of correlation analysis indicated transformational leadership scale and team performance strongly related with each other $r=0.778, p<0.01$.

The correlation coefficient was used to test the relationship between transformational leadership style (single independent variable) and team performance (single dependent variable); the results showed that there is significant relationship between the both the variables considered for the present study. This implies that, irrespective of the leadership style used, the association is apparent. Additionally, it can be innocuous to conclude that leadership style as a single variable has effect on team performance in consort with some other variables that may not be considered in the present study. However, these results may not discount the fact that, traits of a leader and his efficacious leadership style has an important role to play to accomplish individual and organizational objectives (Lussier, 2013). Luthans (2011) had highlighted that leadership style does not only offer positive results but also negative consequences. For this reason, the effect of the leadership style utilized should be taken into consideration in evaluating team performance. To assess the relationship between leadership style and team performance; the correlation coefficient was used. Linear regression analysis was used to envisage how well the independent factor, i.e. transformational leadership style predicts team performance among IT sector respondents.

\subsection{Linear regression analysis}

To identify the effect of independent variable (Transformational Leadership Style) on dependent variable (Team Performance), linear regression analysis was carried out. The results of linear regression analysis are presented in Tables $2-4$. Table 2 provides the $R$ and $R^{2}$ values. The $\mathrm{R}$ value represents the simple correlation and is 0.792 , which specifies a high degree of correlation. The $R^{2}$ value shows the level of variation in the dependent variable, i.e. team performance can be explained by the independent variable, i.e. transformational leadership style. In this case, $64.2 \%$ can be explicated, which is large. 


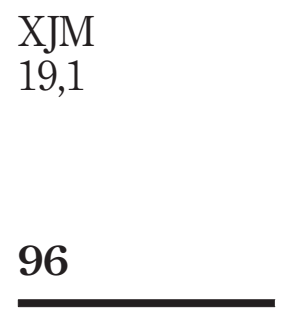

Table 1.

Correlations among transformational leadership subscales and team performance

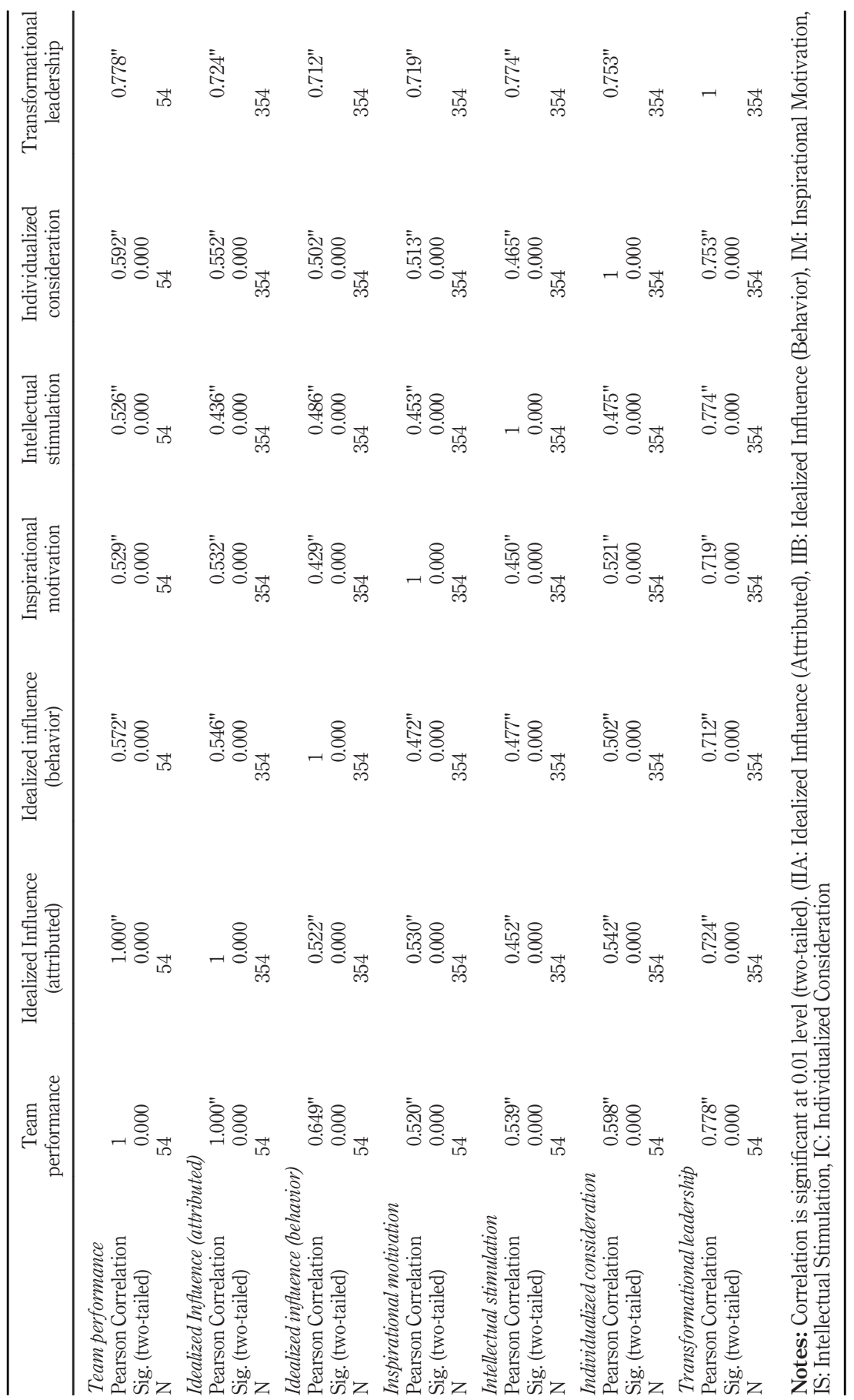


The next table is the ANOVA table, which reports how well the regression equation fits the data (i.e. predicts the dependent variable) and is shown below.

Result of analysis of variance (ANOVA) is presented in Table 3. It is also called as results of model fit. The above Table 3 indicates that the regression model predicts the team performance (i.e. dependent variable) significantly well. This indicates the statistical significance of the regression model. Here, the sig value is less than 0.05 , and specifies that, overall, the regression model statistically significantly predicts the outcome variable (i.e. it is a good fit for the data).

Table 4 indicates the result of coefficients of the regression model. The outcomes of coefficients shows that transformational leadership style positively envisage team performance, standardized $\mathrm{B}=0.781,(p<0.01)$. This result suggests that the team leaders who exhibit transformational leadership style; the performance of their team will increase significantly by $78.1 \%$. This means that transformational leader helps in significantly increasing the performance of its team members.

\section{Discussion of the results}

Transformational leadership style plays an important role and contributes to the overall effectiveness of team. DuBrin (2012) found that a transformational leader is the one who

\begin{tabular}{ccccc}
\hline Model $^{\mathrm{b}}$ & $\mathrm{R}$ & R Square & Adjusted R Square & $\begin{array}{r}\text { Std. Error of } \\
\text { the Estimate }\end{array}$ \\
\hline 1 & $0.792^{\mathrm{a}}$ & 0.692 & 0.642 & 0.489
\end{tabular}

Notes: ${ }^{\text {a }}$ Predictors: (Constant): Transformational Leadership; ${ }^{\mathrm{b}}$ Dependent Variable: Team Performance

Table 2.

Model summary

\begin{tabular}{lccccr}
\hline & \multicolumn{5}{c}{ ANOVA $^{\mathrm{b}}$} \\
Model & Sum of Squares & Df & Mean Square & F Sig & Sig. \\
\hline Regression & 15.696 & 3 & 5.932 & 17.314 & $0.000^{\mathrm{a}}$ \\
Residual & 32.994 & 351 & 0.094 & & \\
Total & & 354 & & &
\end{tabular}



Table 3.

Model fit results

\begin{tabular}{|c|c|c|c|c|c|c|c|c|}
\hline \multirow[b]{2}{*}{ Model } & \multicolumn{2}{|c|}{$\begin{array}{l}\text { Unstandardized } \\
\text { Coefficients }\end{array}$} & \multirow{2}{*}{$\begin{array}{l}\text { Coefficients }^{\mathrm{a}} \\
\text { Standardized } \\
\text { Coefficients } \\
\text { Beta }\end{array}$} & \multicolumn{4}{|c|}{$\begin{array}{l}\text { Collinearity } \\
\text { Statistics }\end{array}$} & \\
\hline & B & Std. Error & & $\mathrm{T}$ & Sig. & Tolerance & VIF & \\
\hline $\begin{array}{l}1 \text { (Constant) } \\
\text { Transformational } \\
\text { Leadership } \\
\text { Note: }{ }^{\text {aDependent }}\end{array}$ & $\begin{array}{l}1.125 \\
\text { riable: }\end{array}$ & $\begin{array}{c}0.110 \\
\text { Im Performa }\end{array}$ & 0.781 & 7.705 & 0.000 & 0.636 & 1.412 & $\begin{array}{c}\text { Table } 4 . \\
\text { Regression } \\
\text { coefficients }\end{array}$ \\
\hline
\end{tabular}


helps organizations and people make positive changes in the way they do things our results suggested the same. Conducing to the writings on transformational leadership and in compliance with the pre-invasion outcomes stated in Kehinde and Banjo (2014), Tsigu and Rao (2015) and Gimuguni et al. (2014), our results suggested that leaders who embrace transformational leadership style are competent to produce successful outcome and also improves team performance. This implies that transformational leaders may improve the performance of their teams by inspiring team members and also by providing them proper direction as well as by motivating them to continue to stay and work together. The researchers and practitioners consider the environment of IT industry as one of the most complex and dynamic industry environment. There are various important results that have been identified by this present research work that can provide suggestion both to researchers and practitioners. The data findings of this study is first illustrated among the transformational leadership behavior in terms of encouraging employees by idealized influence (attributed), idealized influence (behavior), inspirational motivation, intellectual stimulation, individualized consideration the purpose to create positive results in organization.

On one side, the research shows that the individuals who are considered as successful team leaders help their team members to work efficiently and also provide fundamental support to them for accomplishment of team goals. Additionally, it is shown in the literature that the dynamic and complex nature of industry require a dynamic leader and its leadership to manage the changing organizational culture. Therefore, it seems that team leaders will have the ability to boost the degree of teamwork activities by executing an appropriate leadership style. This research has found that transformational leadership style is a most powerful tool used to improve team effectiveness in any organization. The current research is in line with the results found in the study by Zach and Baldegger (2017), who recommended that transformational leader has a significant positive effect on performance.

As it is suggested by the situational theory that an only one leadership style cannot be suitable in the entire situation, different team conditions require different leadership behavior from team leaders; therefore the condition or circumstances in which a team operates has a powerful influence on the use of leadership style. As people respond well to a properly used leadership style and behavior. The preeminent leadership style which should be expounds contingent on the situation in which a leader administer the team and also would lead them towards being effective. This study is inimitable as this provides comprehension on the role of leadership style in improving team performance of the IT Sector. This study is consistent with the previous research studies conducted by Jiang et al. (2016), Andreani and Petrik (2016) and records a positive and significant association between transformational leadership style and team performance.

Though, contrary to our findings, Abdulkadir (2012) and Ojokuku et al. (2012) both witnessed that transformational leadership style has an insignificant negative relationship with team performance. This may be because of lack of experience of leaders at the time of dealing with the problems associated to the management of human resource (Ojokuku et al., 2012).

Transformational leaders emphasize on the importance of tasks that team members participate in at work. Thus, we can put it forward as that transformational leader shows trust in their team member's abilities which encourages them to work and that lead to high performance results. The outcomes obtained from this study are in line with Shafie et al. (2013) who contended that individuals who use transformational leadership style divulge a higher level of performance. But is contrary to the findings of Lather et al. (2009) they observed that transformational leadership style of the leaders do not contribute to the conflict resolution style, extra effort, satisfaction and performance as well as effectiveness of the employees. 


\section{Conclusion}

Team

This research work presents the results of research work on transformational leadership style a boost or hindrance to team performance in the context of IT sector. In many ways transformational leadership style boosts the team performance of an organization. The research findings also confirmed the same. The findings revealed that transformational leadership has direct and positive significant effect on team performance which is supported by some previous research studies.

To ensure organization's success, motivated workforce is required to go beyond their self-interest by alluring to their higher order needs and morality and it needs transformational leaders in any organization. It is believed that transformational leaders have the expertise to bring in, people and the systems on track so there is morality throughout the organization. As shown by the present research that leadership behaviour has direct effect on performance of the team, the present study can be moreover strengthened to explore elements that compose the right balance in leadership behaviours vital to derive projected yield delivery from team members.

It can be concluded from this research study that the team leaders who exhibit transformational leadership style accomplish desired results and better team performance from their team members. In the end, the upcoming researchers should take into account the limitations that manifested in the present study and they should comply with the recommendations in future investigation to avert the same limitations.

\section{Implications}

It has been revealed by many researchers that transformational leadership style could be considered as significant variable that could improve the team performance in an organization. The present study was an endeavor to enhance value of the current literature in the corporate management situation, particularly for the IT sector. Furthermore, the outcomes from the present study may help team leaders in identifying the role of transformational leaders to boost team member's moral and as a result improved team performance which is very much required for organizational success.

This research examination may have a lot of implications for industry experts, researchers, academicians and practitioners relating to IT sector. Researchers can consider the present study as a base as it focuses only on one of the significant type of leadership style, i.e. transformational leadership style and its effect on team performance especially in IT sector. However, the scope of study could be further expanded by including different types of leadership styles as well as different emerging industry sectors. One of the key implications from researcher point of view could be to broaden the scope of study by comparing the effect of various leadership styles in different sectors as well as to identify the most promising styles of leadership in varied sectors.

The result of the present study shows that that all the constituents of transformational leadership (i.e. idealized influence [attributed], idealized influence [behavior], inspirational motivation, intellectual stimulation, individualized consideration) are applicable in the Indian IT sector which provides a guideline for the managers and decision-makers to make utmost use of these constituents to improve their team performance. Among all the constituents of transformational leadership idealized influence (attributed) and idealized influence (behavior) play major role in improving team performance, this highlights that team leaders must be well acquainted with the same.

The important theoretical implication of the present study is an empirical study of IT companies emphasizing the importance of leadership when evaluating team performance. Even though this concept is based on previous concepts of leadership and performance, 
particularly the transformational style (Wang et al., 2011), this research adds to the leadership literature the effects of transformational leadership in the context of IT sector (Zach and Baldegger, 2017).

\section{Limitations and further research}

There are certain limitations of the present study. Few limitations of this research work are that the data collected for this research work is non-cognitive in nature and simultaneously respondents may incline to evaluate the positive facets of opinion poll more propitiously than negative facets. Secondly, the data has been collected only from companies located in Pune. Other limitation is that the only very few demographic information has been collected for present research examination and that too was not taken into consideration while measuring team performance. The research could have been more substantive if this examination would have considered wide-range of variances among these teams for example gender differences on the effects of leadership styles on team performance. There are certain other factors which play an important role in improving team performance such as organizational culture, employee contentment, enthusiasm and commitment. Hence, future studies can be carried out to discover thoroughly the effect of these variables on team performance. Additionally, only IT sector has been considered for this examination; other researchers can consider other sectors with diverse mode of operations so as to achieve a strong base for conclusions and decision concerning leadership styles and team performance. The significant results related the relationship between transformational leadership and the team performance can be swayed by the statistic that all data was collected from the similar source also no mediation effect was witnessed at the time of assessing the team performance by team leaders. Though psychometric attributes of the measures utilized in this examination are admissible, other studies might use different scale to conquer these issues.

\section{References}

Abdulkadir, D.S. (2012), "Strategic human resource management and organizational performance in the Nigerian insurance industry: the impact of organizational climate", Business Intelligence Journal, Vol. 5 No. 1, pp. 8-20.

Antonakis, J. (2014), "Instrumental leadership: Measurement and extension of transformationaltransactional leadership theory", The Leadership Quarterly, Vol. 25 No. 4, pp. 746-771.

Athukorala, C., Perera, I. and Meedeniya, D. (2016), "The impact of transformational and transactional leadership styles on knowledge creation in Sri Lankan software industry," 2016 Moratuwa Engineering Research Conference, pp. 309-314.

Athukorala, C., Perera, I. and Meedeniya, D. (2016), "The impact of transformational and transactional leadership styles on knowledge creation in Sri Lankan software industry," 2016 Moratuwa Engineering Research Conference, pp. 309-314.

Andreani, F. and Petrik, A. (2016), "Employee performance as the impact of transformational leadership and job satisfaction in Pt Anugerah Baru Denpasar", Journal of Management and JMK, Vol. 18 No. 1, pp. 25-32.

Avolio, B.J. (2010), Full Range Leadership Development, Sage, Thousand Oaks, CA.

Avolio, B.J. and Bass, B.M. (2004), "Transformational leadership and organizational commitment: Mediating role of psychological empowerment and moderating role of structural distance", Journal of Organizational Behavior, Vol. 25 No. 8, pp. 951-968.

Bacha, E. (2014), "The relationship between transformational leadership, task performance and job characteristics", Journal of Management Development, Vol. 33 No. 4, pp. 410-420. 
Barling, J., Loughlin, C., Kevin Kelloway, E. and Turner, N. (2012), “Transformational leadership and employee psychological well-being: The mediating role of employee trust in leadership", Work \& Stress: An International Journal of Work, Health \& Organizations, Vol. 26 No. 1, pp. 39-55.

Barrick, M.R. (1998), "Relating member ability and personality to work team processes and team effectiveness", Journal of Applied Psychology, Vol. 83 No. 3, pp. 377-391.

Bass, B.M. (1987), "Biography and the assessment of transformational leadership at the world-class level", Journal of Management, Vol. 13 No. 1, pp. 7-19.

Bass, B.M. (1997), Full-Range of Leadership Development: Manual for the Multifactor Leadership Questionnaire, Mind Garden, Palo Alto, CA.

Bass, B.M. and Avolio, B.J. (1997), Full-Range of Leadership Development: Manual For The Multifactor Leadership Questionnaire, Mind Garden, Palo Alto, CA.

Bass, B.M. (1999), "Two decades of research and development in transformational leadership", European Journal of Work and Organizational Psychology, Vol. 8 No. 1, pp. 9-32.

Bass, B.M. (2000), MLQ Multifactor Leadership Questionnaire, Mind Garden, Redwood City.

Bass, B.M. (2009), The Bass Handbook of Leadership: Theory, Research, and Managerial Applications, Free Press, New York, NY.

Bass, B.M. (1990), "From transactional to transformational leadership: learning to share the vision", Organizational Dynamics, Vol. 18 No. 3, pp. 19-32.

Bass, B.M. (1995), Improving Organizational Effectiveness through Transformational Leadership, Sage Publications, Thousand Oaks, CA.

Bhatnagar, D.A. (2012), "Leader values for constructive controversy and team effectiveness in India", The International Journal of Human Resource Management, Vol. 23 No. 1, pp. 109-125.

Burns, J.M. (1978), Leadership, Harper and Row, MI.

Carasco-Saul, M.K. (2015), "Leadership and employee engagement proposing research agendas through a review of literature", Human Resource Development Review, Vol. 14 No. 1, pp. 38-63.

Castelli, P.A. (2016), "Reflective leadership review: a framework for improving organisational performance", Journal of Management Development, Vol. 35 No. 2, pp. 217-236.

Chun, J.C. (2016), "A multilevel study of group-focused and individual-focused transformational leadership, social exchange relationships, and performance in teams", Journal of Organizational Behavior, Vol. 37 No. 3, pp. 374-396.

Cohen, S.G. (1997), "What makes teams work: group effectiveness research from the shop floor to the executive suite", Journal of Management, Vol. 23 No. 3, pp. 239-290.

Chamika, M.W. and Gunasekara (2016), "The Impact of Leadership Styles on Employee Performance", Proceedings of the Undergraduates Research Conference - 2016, 11th January 2017, Department of Accountancy, Faculty of Commerce and Management Studies, University of Kelaniya.

Collins, J. (2014), "Transformational leadership: the most effective leadership style? Wattsnext insourced", HR Directors, available at: www.wattsnext.com.au/Transformational-LeadershipThe-most-effective-leadership-style

Crane, B.A. (2018), "Developing employees' mental complexity: transformational leadership as a catalyst in employee development", Human Resource Development Review, Vol. 17 No. 3, pp. 234-257.

Dionne, S.D. (2010), "The role of leadership in shared mental model convergence and team performance improvement: an agent-based computational model", The Leadership Quarterly, Vol. 21 No. 6, pp. 1035-1049.

Dubrin, A. (2012), Leadership: Research Findings, Practice and Skills, 7th ed., Houghton Mifflin, Boston, MA.

DeGroot, T.K. (2000), "A meta-analysis to review organizational outcomes related to charismatic leadership”, Canadian Journal of Administrative Sciences/Revue Canadienne Des Sciences de L'Administration, Vol. 17 No. 4, pp. 356-371. 
Dimas, I.D. (2016), Work Teams - Assessment Instruments.

Dionne, S.D. (2010), "The role of leadership in shared mental model convergence and team performance improvement: an agent-based computational model”, The Leadership Quarterly, Vol. 21 No. 6, pp. 1035-1049.

Dhammika, K.A.S, Ahmad, F.B. and Sam, T.L. (2013), "Transactional, transformational, union and organizational commitment: An examination of the effect flaws, International Journal of Business and Social Science, Vol. 4 No. 6.

Dvir, T.E. (2002), "Impact of transformational leadership on follower development and performance: a field experiment", Academy of Management Journal, Vol. 45, pp. 735-744.

Edmonson, C.S. (2017), "The leader role in crisis management", JONA: The Journal of Nursing Administration, Vol. 46 No. 9, pp. 417-419.

Fernet, C.T.S. (2015), "Transformational leadership and optimal functioning at work: on the mediating role of employees' perceived job characteristics and motivation", Work and Stress, Vol. 29 No. 1, pp. 11-31.

Fiedler, F. (1996), "Research on leadership selection and training: one view of the future", Administrative Science Quarterly, Vol. 41 No. 2, pp. 241-250.

Fleishman, E.A. (1991), "Taxonomic efforts in the description of leader behavior: a synthesis and functional interpretation", The Leadership Quarterly, Vol. 2 No. 4, pp. 245-287.

Gillet, N.A. (2014), "Transformational leadership and organizational commitment: the mediating role of job characteristics", Human Resource Development Quarterly, Vol. 25 No. 3, pp. 321-347.

Gimuguni, L., Nandutu, J. and Magolo, A. (2014), Effect of Leadership Styles on Performance of Local Governments in Uganda, A case of Mbale District.

Gumusluoglu, L. and Isev, A. (2007), "Transformational leadership, creativity and organizational innovation", Journal of Business Research, Vol. 62 No. 4, pp. 461-473.

Hackman, J.R. (2012), "From causes to conditions in group research", Journal of Organizational Behavior, Vol. 33 No. 3, pp. 428-444.

Hancott, D. (2005), "The relationship between transformational leadership and organisational performance in the largest public companies in Canada", Minneapolis: Doctoral Dissertation, Capella University.

Haque, A.F. (2017), "The relationship between female representation at strategic level and firm's competitiveness: evidences from cargo logistic firms of Pakistan and Canada", Polish Journal of Management Studies, Vol. 15 No. 2, pp. 69-81.

Hiller, N.J. (2006), "Collective enactment of leadership roles and team effectiveness: a field study", The Leadership Quarterly, Vol. 17 No. 4, pp. 387-397.

Jiang, W., Lu, Y. and Le, Y. (2016), "Trust and project success: a twofold perspective between owners and contractors", Journal of Management in Engineering, Vol. 32 No. 6, pp. 04016022.

Jones, D. and Rudd, R. (2008), "Transactional, transformational, or laissez- faire leadership: An assessment of college of agriculture academic program leaders' (Deans) leadership styles", Journal of Agricultural Education, Vol. 49 No. 2, pp. 88-97.

Judge, T.A. (2004), "Transformational and transactional leadership: a meta-analytic test of their relative validity", Journal of Applied Psychology, Vol. 89 No. 5, pp. 755-768.

Kerr, S. and Jermier, J.M. (1977), "Substitutes for leadership: Their meaning and measurement", Organizational Behavior and Human Performance, Vol. 22, pp. 375-403.

Khan, S.A. (2017), "To evaluate the impact of transformational leadership on organizational learning", International Journal of Research in Commerce and Management, Vol. 8 No. 9, pp. 1-6.

Kehinde Obasan, A. and Hassan Banjo, A. (2014), "A Test of the Impact of Leadership Styles on Employee Performance: A Study of Department of Petroleum Resources," International Journal of Management Sciences, Research Academy of Social Sciences, Vol. 2 No. 3, pp. 149-160. 
Kim, W.K. (1992), “Parables of leadership”, Harvard Business Review, Vol. 123.

Lopez-Dominguez, M., Enache, M., Sallan, J. and Simo, P. (2014), “Transformational leadership as an antecedent of change oriented organizational citizenship behavior", Journal of Business Research, Vol. 66 No. 10, pp. 2147-2152.

Lussier, RN. (2013), Management Fundamentals, 4th ed., South Western: Cengage Learning, Mason, $\mathrm{OH}$.

Luthans, F. (2012), Organizational behavior : An Evidence-Based Approach, McGraw-Hill, New York, pp. $428-430$.

Lather, A., Singh, Jain, V.K., Jain, Silpha. and Vikas, S. (2009), "Leadership styles in relation to conflict resolution modes: a study of Delhi Jal board (DJB)", Vilakshan: The XIMB Journal of Management. Mar2009, Vol. 6 No. 1, pp. 19-38.

Lourenço, P.R. (2004), "Group effectiveness: analysis and discussion of a multidimensional model", Psychological, Extra-Series, pp. 611-621.

Marieke van der Hoek, S.G. (2016), "Goal setting in teams: goal clarity and team, performance in the public sector", Review of Public Personnel Administration, pp. 1-22.

Mathieu, J.M. (2008), "Team effectiveness 1997-2007: a review of recent advancements and a glimpse into the future", Journal of Management, Vol. 34 No. 3, pp. 410-476.

Mokgolo, M.M. (2012), "Transformational leadership in the South African public service after the April 2009 national elections", South African Journal of Human Management, Vol. 1 No. 1, pp. 2-9.

Mwita, J.I. (2000), "Performance management model: a systems-based approach to public service quality", International Journal of Public Sector Management, Vol. 13 No. 1, pp. 19-37.

Ndunge, W.E. (2014), "Strategic leadership and change management practices at the Kenya wildlife service", Doctoral dissertation, University of Nairobi.

Northouse, P.G. (2015), Leadership: Theory and Practice, Sage publications, Thousand Oaks.

Palestini, R.H. (2009), From leadership theory to practice: A game plan for success as a leader, Rowman \& Littlefield Education, pp. 25-26.

Obiwuru, T. (2011), "Effects of leadership style on organisational performance", Journal of Business and Management Research, Vol. 1 No. 7, pp. 100-111.

Ojokuku, R.M., Odetayo, T.A. and Sajuyigbe, A.S. (2012), "Impact of leadership style on organizational performance: a case study of Nigerian banks", American Journal of Business and Management, Vol. 2 No. 1, pp. 202-207.

Pawirosumarto, S.S. (2017), "Factors affecting employee performance of PT.Kiyokuni Indonesia", International Journal of Law and Management, Vol. 59 No. 4, pp. 602-614.

Polychroniou, P.V. (2009), "Relationship between emotional intelligence and transformational leadership of supervisors: the impact on team effectiveness", Team Performance Management: An International Journal, Vol. 15 Nos 7/8, pp. 343-356.

Rotberg, R.I. (2014), "The need for strengthened political leadership”, The ANNALS of the American Academy of Political and Social Science, Vol. 652 No. 1, pp. 238-256.

Rousseau, V. \&. (2010), "Team self-managing behaviors and team effectiveness: the moderating effect of task routineness", Group and Organization Management, Vol. 35 No. 6, pp. 771-781.

Salas, E.C. (2008), "On teams, teamwork, and team performance: discoveries and developments", Human Factors: The Journal of the Human Factors and Ergonomics Society, Vol. 50 No. 3, pp. 540-547.

Singh, N. and Krishnan, V.R. (2007), "Transformational leadership in India: Developing and validating a new scale using grounded theory approach", International Journal of Cross - Cultural Management, Vol. 7 No. 2, pp. 219-236.

Sani and Maharani (2012), "The impacts of transformational leadership and organizational commitment on job performance with the among lecturers of faculty in the Islamic Maulana 
$\mathrm{XJM}$

19,1

104

Malik Ibrahim Malang University: the mediating effects of organizational citizenship behavior", International Journal of Academic Research Part B, Vol. 4 No. 4, pp. 99-103.

Shafie, B., Baghersalimi, S. and Barghi, V. (2013), "The relationship between leadership style and employee performance (case study of real estate registration organization of Tehran province)", Singaporean Journal of Business, Economics and Management Studies, Vol. 2 No. 5, pp. 21-29, doi: $10.12816 / 0003885$.

Somboonpakom, A. \&. (2014), "Shared leadership and shared vision as predictors for team learning process, synergy and effectiveness in healthcare industry", International Journal of Innovation and Learning, Vol. 16 No. 4, pp. 78-91.

Stogdill, R.M. (1974), Handbook of Leadership, a Survey of Theory and Research, Free Press.

Strauss, K.G. (2009), "Proactivity directed toward the team and organization: the role of leadership, commitment and role-breadth self-efficacy", British Journal of Management, Vol. 20 No. 3, pp. 279-291.

Sudhakar, G.F. (2011), "Soft factors affecting the performance of software development teams", Team Performance Management: An International Journal, Vol. 17 Nos 3/4, pp. 187-205.

Susan, K. (2014), "Mission-Driven followership and civic engagement: a different sustainable energy", Journal of Leadership Education, Vol. 13 No. 14, pp. 76-87.

Tajasom, A. (2015), "The role of transformational leadership in innovation performance of Malaysian SMEs", Asian Journal of Technology Innovation, Vol. 23 No. 2, pp. 172-188.

Tepper, B.D. (2018), "Examining follower responses to transformational leadership from a dynamic, person-environment fit perspective", Academy of Management Journal, Vol. 61 No. 4, pp. 1343-1368.

Thomas, W.H.N. (2017), "Transformational leadership and performance outcomes: analyses of multiple mediation pathways", Leadership Quaterly, Vol. 28 No. 3, pp. 385-417.

Trottier, T.V. (2008), "Examining the nature and significance of leadership in government organizations", Public Administration Review, Vol. 68 No. 2, pp. 319-333.

Tsigu, G.T. and Rao, D.P. (2015), "Leadership styles: their impact on job outcomes in Ethiopian banking industry", ZENITH International Journal of Business Economics and Management Research, Vol. 5 No. 2, pp. 41-52.

Van der Vegt, G.S. (2005), "Learning and performance in multidisciplinary teams: the importance of collective team identification”, Academy of Management Journal, Vol. 48 No. 3, pp. 532-547.

Vinger, G. (2009), "The restructuring of a university: a call for the exhibition of transformational leadership behaviours", The International Journal of Learning: Annual Review, Vol. 16 No. 10, pp. 267-286.

Van Knippenberg, D.\&. (2013), "A critical assessment of charismatic - transformational leadership research: back to the drawing board?", Academy of Management Annals, Vol. 7 No. 1, pp. 983-1007.

Walumbwa, F.O. (2004), "The role of collective efficacy in the relations between transformational leadership and work outcomes", Journal of Occupational and Organizational Psychology, Vol. 77 No. 4, pp. 515-530.

Wang, D.D. (2014), “A meta-analysis of shared leadership and team effectiveness”, Journal of Applied Psychology, Vol. 99 No. 2, pp. 191-198.

Wang, D.D. (2014), “A Meta-analysis of shared leadership and team effectiveness”, Journal of Applied Psychology, Vol. 99 No. 2, pp. 191-198.

Wang, H.J. (2017), “Transformational leadership, adaptability, and job crafting: the moderating role of organizational identification", Journal of Vocational Behavior, Vol. 100, pp. 185-195.

Wang, X.-H. (2012), "A multilevel study of transformational leadership, identification, and follower outcomes”, The Leadership Quarterly, Vol. 23 No. 5, pp. 775-790. 
Weimar, E.N. (2013), "Towards high performance software teamwork", Proceedings of the 17th International Conference on Evaluation and Assessment in Software Engineering in Porto de Galinhas, in EASE 2013, pp. 212-215, Brazil, 2013, ACM, New York, NY.

Winkler, I. (2010), Contemporary Leadership Theories: Enhancing the Understanding of the Complexity, Subjectivity and Dynamic of Leadership, New York, NY, Springer Science + Business Media.

Yukl, G.A. (2013), Leadership in Organizations, 8th ed., Pearson Education, UpperSaddle River, NJ.

Zach, L. (2018), "Five different types of leadership styles", available at: https://smallbusiness.chron. com/5-different-types-leadership-styles-17584.html

\section{Further reading}

Alan, M. (2013), “Leadership styles”, Retrieved May Saturday, 2020, available at: www.ofd.ncsu.edu/ wp-content/leadership: www.ofd.ncsu.edu/wp-content/leadership

Amin, M.E. (2005), Social Science Research Conceptions, Methodology and Analysis, Makerere University, Kampala.

Asare, O.M. (2012), "In, an empirical investigation between leadership style and organizational performance", Hawaii: Doctorate thesis, Atlantic International University Honolulu.

Asrar-Ul-Haq, M. and Kuchinke, K.P. (2016), "Impact of leadership styles on employees' attitude towards their leader and performance: empirical evidence from Pakistani banks", Future Business Journal, Vol. 2 No. 1, pp. 54-64.

Aziz, R.A. (2013), "The effects of leadership styles on the business performance of SMES in Malaysia”, International Journal of Business, Economics and Accounting, Vol. 2, pp. 45-52.

K, B., B. (2003), "Transformational leadership: an examination of cross-national differences and similarities", Leadership and Organization Development Journal, Vol. 24 Nos 1/2, pp. 5-17.

B.M, B. (1986), Leadership and Performance beyond Expectations, Free Press, New York, NY.

Bass, B.M. (1995), Improving Organizational Effectiveness through Transformational Leadership, Sage Publications, Thousand Oaks, CA.

Bormann, K.C. and Rowold, J. (2018), "Construct proliferation in leadership style research: reviewing pro and contra arguments", Organizational Psychology Review, Vol. 8 Nos 2/3, pp. 149-173.

Chandra, T. \&. (2016), "The influence of leadership styles, work environment and job satisfaction of employee performance", International Education Studies, Vol. 9 No. 1, pp. 131-140.

Isabel, M. and D, C. (2018), "Information systems project teams: factors for high performance", Team Performance Management: An International Journal.

Jong, J., Hartog, D. and John, M.C. (2014), "Leadership style, school climate, and the institutional commitment of teachers", In International Forum Journal, Vol. 1 No. 2, pp. 167-184.

Niti Singh, V.R. (2007), "Transformational leadership in India: developing and validating a new scale using grounded theory approach", International Journal of Cross Cultural Management, Vol. 7 No. 2, pp. 219-236.

Nunnally, J.A. (1994), “The assessment of reliability”, Psychometric Theory, Vol. 3, pp. 248-292.

\section{Corresponding author}

Rajni Gyanchandani can be contacted at: rajni.gyanchandani@gmail.com

For instructions on how to order reprints of this article, please visit our website:

www.emeraldgrouppublishing.com/licensing/reprints.htm

Or contact us for further details: permissions@emeraldinsight.com 